\title{
PREDICTING THE IMPACT OF COMMERCIALIZATION FACTORS ON THE SOCIAL MISSION OF ISLAMIC MICROFINANCE INSTITUTIONS FOR MUSLIM COMMUNITIES
}

\author{
Hesi Eka Puteri ${ }^{1}$ \\ ${ }^{1}$ State Islamic Institute of Bukittinggi, Indonesia, e-mail: besiekaputeri@iainbukittinggi.ac.id \\ (c) (1) (2) \\ C2020 by the authors. Submitted for possible open access publication under the terms and conditions of the Creative Commons \\ Attribution-ShareAlike 4.0 International License-(CC-BY-SA) (https://creativecommons.org/licenses/by-sa/4.0/) \\ do) DOI : http://dx.doi.ong/10.30983/islam realitas.v6i1.3095

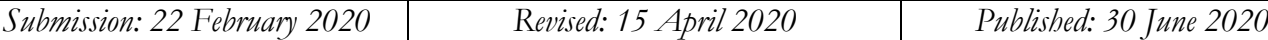

\begin{abstract}
This study examines the impact of commercialization factors, covering profitability, regulation, and competition, on the social performance of Islamic rural banks that cater specifically to the Muslim community. As a community banking institution operating by Islamic principles, Islamic rural banks are faced with two performance targets, namely financial performance and social performance, both of which are interrelated. This study is quantitative research based on a survey on six units of Islamic rural banks in West Sumatra. Data from the financial services authority and other financial documents at Islamic rural banks are analyzed with panel data regression. The findings of this research show that profitability and competition influence social performance. Meanwhile, there is no regulation's impact on social performance. Regulatory factors that were initially expected to strengthen the social responsibility mission of Islamic rural banks did not stimulate the increase of social performance. This study reveals the importance of the commercialization factor in improving the social performance of Islamic rural banks which aims at increasing the social benefits for the low-income Muslim community.
\end{abstract}

Keywords: Commercialization; Social performance; Islamic rural banks; Microfinance institutions

\begin{abstract}
Abstrak
Penelitian ini bertujuan untuk menguji dampak dari faktor-faktor komersialisasi yang meliputi profitabilitas, regulasi dan kompetisi terhadap kinerja sosial BPR Syariah khususnya kepada penggunanya yaitu masyarakat Muslim. Sebagai sebuah community banking yang beroperasi dalam prinsip-prinsip Islam, BPR Syariah dihadapkan pada dua target kinerja yaitu kinerja kenangan dan kinerja sosial yang keduanya saling terkait. Penelitian ini menggunakan pendekatan kuantitatif berdasarkan survei pada enam unit BPR Syariah di provinsi Sumatera Barat, Data dikumpulkan dari Otoritas Jasa Keuangan dan dokumen di BPR Syariah kemudian dianalisis dengan regresi data panel. Hasil penelitian ini menunjukkean bahwa profitabilitas dan persaingan berpengarub terbadap kinerja sosial, sedangkan regulasi tidak berpengarub terhadap kinerja sosial. Faktor regulasi yang semula diharapkan memperkuat misi tanggung jawab sosial BPR syariah, ternyata tidak merangsang peningkatan kinerja sosial. Studi ini mengungkap akan pentingnya faktor komersialisasi dalam meningkatkan kinerja sosial BPR syariah dengan meningkatkan manfaat sosial untuk masyarakat Muslim berpenghasilan rendah.
\end{abstract}

Kata Kunci: Komersialisasi; Kinerja sosial; Bank Pembiayaan Rakyat Syariah (BPRS); Lembaga kenangan mikro

\section{Background}

The concept of social performance in Islamic rural banks refers to the role played by these institutions in economic development or in how far microfinance has provided social benefits to poor people, which could be measured by the outreach. As a kind of formal microfinance institution, the concept of social performance in Islamic rural banks more specifically refers to the extent to which the financial institutions can serve the low-income community. ${ }^{1}$ Yunus has shown that while many low-income communities are entrepreneurs, most of them do not have receive support and opportunities from financial institutions, by means of which they would have been able to
${ }^{1}$ Roy Mersland and R Øystein Strøm, 'Microfinance Financial and Social Performance: An Introduction in Microfinance Institutions', in Microfinance Institutions (Palgrave Macmillan, London: Springer, 2014), pp. 1-11; B E N Soltane Bassem, 'Social and Financial
Performance of Microfinance Institutions: Is There a Trade-Off ?', Journal of Economics and International Finance, 4.4 (2012), 92-100. 
free themselves from poverty and contribute to economic development. ${ }^{2}$

If financial performance is regulated by the monetary authority, social performance in Islamic rural banks need not be regulated. Islamic rural banks carry out social missions as the underlying philosophy of their operations. Islamic banks can be differentiated from conventional banks in three major aspects: foundations, management, and products. ${ }^{3}$ Theoretically, the concept of social responsibility in Islamic banks is based on five Islamic principles, namely, tawhid (monotheism), shariah (Divine Law), justice, benevolence, and maslaha (common good), and all these principles distinguish Islamic banks' social function practices from those of conventional banks. ${ }^{4}$ Thus, Islamic rural banks are different from other microfinance institutions (MFI) because of the responsibility they have in implementing social performance, above and beyond their financial performance target. The Islamic rural bank is expected to be able to fulfill the capital

2 Muhammad Yunus, Creating a World Without Poverty: Social Business and the Future of Capitalism (New York: Public Affairs, 2009); Milford Bateman, The Rise and Fall of Muhammad Yunus and the Microcredit Model, Management: Leading \& Collaborating in Competitive World, 11Th (Edition. McGraw-Hill Education, 2014).

3Samy Nathan and Vincent Ribière, 'From Knowledge to Wisdom: The Case of Corporate Governance in Islamic Banking', VINE: The Journal of Information and Knowledge Management Systems, 37.4 (2007), 471-83

<https://doi.org/10.1108/03055720710838533>; Rihab Grassa and Hamadi Matoussi, 'Corporate Governance of Islamic Banks: A Comparative Study between GCC and Southeast Asia Countries', International Journal of Islamic and Middle Eastern Finance and Management, 7.3 (2014), 346-62.

${ }_{4}$ Mohamad Yazis Ali Basah and Mazlynda Md Yusuf, 'Islamic Bank and Corporate Social Responsibility (CSR)', European Journal of Business and Management, 5.11 (2013), 194-209.

5 Viloria Amelec and Vasquez Carmen, 'Relationship Between Variables of Performance Social and Financial of Microfinance Institutions', Advanced Science Letters, $21.6 \quad$ (2015), 1931-34 $<$ https://doi.org/https://doi.org/10.1166/asl.2015.616 $3>$.

${ }^{6}$ Robert Cull, Asli Demirguc-Kunt, and Jonathan Morduch, Microfinance Tradeoffs: Regulation, Competition, and Financing In The Handbook of Microfinance (The Handbook Of Microfinance, 2011); Erasmus Fabian Kipesha and needs of the community that has limited access to commercial banks, requiring small credit ceiling and easily accessible financing with easier collateral.

Nevertheless, although the social function is one of the basic operational concepts in Islamic banks, this financial institution is not a social institution. As a profit-oriented institution, social performance in this financial institution must be in line with its financial performance. ${ }^{5}$ The problem that often occurs at Islamic rural banks is the difficulty in achieving these two performance targets simultaneously. Islamic rural banks were designed not only to assist low-income people, but to be able to sustain itself financially, as they are not subsidized by the government. At several rural banks, trade-offs between these two performances targets sometimes occur. ${ }^{6}$ However, previous studies have shown that the two aims of MFIs could be achieved at the same time?

Xianzhi Zhang, 'Sustainability, Profitability, and Outreach Tradeoffs: Evidence from Microfinance Institutions in East Africa', European Journal of Business and Management, 5.8 (2013), 136-49; Adams Abdulai and Devi Datt Tewari, 'Trade-off Between Outreach and Sustainability of Microfinance Institutions: Evidence From Sub-Saharan Africa', Enterprise Development and Microfinance, $28.3 \quad$ (2017), 162-81 <https://doi.org/https://doi.org/10.3362/1755-

1986.16-00014>; Begum Ismat Ara Huq and others, 'Examining the Trade-off Between Social Outreach and Financial Efficiency: Evidence from Microfinance Institutions in South Asia', Global Business Review, 18.1 (2017), 617-828 <https://doi.org/10.1177/0972150917692169>.

${ }^{7}$ Bassem; Maurizio Caserta, Simona Monteleone, and Francesco Reito, 'The Trade-off Between Profitability and Outreach in Microfinance', Economic Modelling, $\quad 72 \quad$ (2018), 31-41 <https://doi.org/https://doi.org/10.1016/j.econmod.2 018.01.003 >; Kamlesh Gakhar and Meetu, 'Financial Performance and Outreach of Microfinance Institutions: Is There a Trade-Off ? - An Empirical Study of Indian', Sona Global Management Review, 7.4 (2013), 1-10; Maxime Lebovics, Niels Hermes, and Marek Hudon, 'Are Financial and Social Efficiency Mutually Exclusive? A Case Study of Vietnamese Microfinance Institutions', Annals of Public and Cooperative Economics, 87.1 (2016), 5577; Zhang Qinlan and Yoichi Izumida, 'Determinants of Repayment Performance of Group Lending in China', 
Even though Islamic rural banks are established upon Islamic principles which give large space in the implementation of social functions, still the target of social performance is constrained by various commercialization factors that support the achievement of the social performance. Some commercialization factors have been identified as the cause of the relative failure in the achievement of social performance at microfinance institutions. ${ }^{8}$

One of the very popular commercialization factors is profitability. A number of studies have suggested that there exists a link between profitability and outreach, because a bank's decision to enter a certain market segment is driven by the expected profitability of that segment. ${ }^{9}$ Other studies used Return on Assets (ROA) as a proxy for profitability ${ }^{10}$ and some of them concluded that profitability negatively impacted outreach to the poor; this indicates the presence of trade-offs between financial and social performances. ${ }^{11}$

Furthermore, regulation played an important role in expanding the outreach, especially for the capital structure's regulation. In practice, making a bridge between social goals

China Agricultural Economic Review, 5.3 (2013), 328-41 $<$ https://doi.org/10.1108/CAER-08-2012-0083>;

Bereket Zerai and Lalitha Rani, 'Is There a Trade-off Between Outreach and Sustainability of Microfinance Institutions? Evidence from Indian Microfinance Institutions (MFIs)', European Journal of Business and Management, 4.2 (2012), 90-99; Lincolin Arsyad, 'Microfinance Institutions, Institutional Performance and Sustainability', Andi Offset. Yogyakarta, 2008.

8 Zerai and Rani; Qinlan and Izumida; Prabhjot Kaur, 'Outreach and Sustainability of Microfinance Institutions in India in Pre and Post Andhra Pradesh Microfinance Crisis in Context of South Asia', Global Journal of Finance and Management, 6.6 (2014), 569-74; Aderaw Gashayie, 'Factors That Affect Financial Sustainability of Microfinance Institution: Literature Review', European Journal of Business and Management, 7.7 (2015), 223-29.

${ }^{9}$ Timothy F Bresnahan and Peter C Reiss, 'Entry And Competition In Concentrated Markets', Journal of Political Economy, 99.5 (1991), 977-1009.

${ }^{10}$ Isabelle Piot-lepetit and Joseph Nzongang, 'Financial Sustainability and Poverty Outreach Within a Network of Village Banks in Cameroon: A Multi-DEA Approach', European Journal of Operational Research, 234.1 (2014), and financial goals can be achieved by improving the allocation of capital. ${ }^{12}$ A number of studies have linked the capital structure to financial performance, but do not analyze the impact on social performance. Capital Adequacy Ratio (CAR) is one indicator of capital adequacy that must be maintained to ensure the sustainability of the social mission. Axmann concluded that the transformation in a business model due to regulations lead to higher costs per dollar lent, ultimately affecting outreach and also social performance. ${ }^{13}$ Like an engine or bumper, capital serves to overcome the incident of a shock and keep away from bankruptcy. ${ }^{14}$

Competition in rural banks was also identified as a distinct factor for rural banks' sustainability because it could encourage innovation of products and services with interest rates as instruments. Competitive advantage built through interest rates or financing margins can expand the outreach of microfinance institutions. ${ }^{15}$ This condition no doubt implies a significant negative effect between competition and outreach. Studies have shown the significant negative effect between competition and outreach, ${ }^{16}$ because the

<https://doi.org/10.1016/j.ejor.2013.10.004>; Kipesha and Zhang.

${ }^{11}$ Kipesha and Zhang.

${ }^{12}$ Cull, Demirguc-Kunt, and Morduch.

${ }^{13}$ Nikolaus Axmann, 'What Is the Effect of Regulatory Supervision on the Profitability and Outreach of Microfinance Institutions?', Southeast Asian Journal of Economics, 3.1 (2015), 1-25.

${ }^{14}$ Robert Cull, Asli Demirgüç-Kunt, and Jonathan Morduch, 'Does Regulatory Supervision Curtail Microfinance Profitability and Outreach?', World Development, $\quad 39.6 \quad$ (2011), 949-65 <https://doi.org/10.1016/j.worlddev.2009.10.016>; Ndi Gwasi and Marcel T. Ngambi, 'Competition and Performance of Microfinance Institutions in Cameroon', International Journal of Research In Social Sciences, 3.8 (2014), 1-36 <https://doi.org/10.2139/ssrn.2029568>.

${ }^{15}$ Abdulai Adams and Devi D. Tewarib, 'Determinants of Microfinance Outreach in Sub-Saharan Africa: A Panel Approach', Acta Commercii, 17.1 (2017), 1-10 <https://doi.org/10.4102/ac.v17i1.414>.

16 Arne De Cloet and Hartwig Moyaert, Microfinance: Influence of Competition on Outreach, Published Thesis of Ghent University, 2014; T D Olsen, 'New Actors in Microfinance Lending: The Role of Regulation and Competition in Latin America', Perspectives on Global 
increase in competition reduced the number of clients and ultimately rendered microfinance institutions inefficient. However, other studies have shown that although the competition effect was negative on financial self-sufficiency, it did not limit the extent of outreach.

This study aims to explore the effect of commercialization factors, covering profitability, regulation, and competition, on the social performance of Islamic rural banks in West Sumatra Province. This study deserved further analysis because of the inconsistency of the previous findings. Some of them found that commercialization factors had an impact on social performance achievements, but others did not. Some microfinance institutions with feasible financial performance showed good social performance while others did not. ${ }^{17}$

Choosing the Islamic rural banks as a case study can provide a new perspective on the link between profitability, regulation, and competition and their impact on social performance. These types of financial institutions are categorized by the institutionalist approach as microfinance institutions. They are not subsidized by the government. Thus, financial sustainability is one of the main requirements for the implementation of their social function. This study is therefore a policy study about the development of Islamic rural banks that are widely predicted to be marginalized because of competition. However, Islamic rural banks should be presented as a financial institution that has a feasible social performance and has sustainability. These Islamic rural banks exist as a reference financial institution that is usury-free and advances social justice because this bank grows in a Muslim community and having features as a social justice-oriented financial institution. This study will show the reasons why the social function of Islamic rural banks run well at some but fail at others. It will also discuss the factors that lead to success or failure. If successful, this study can assist in the development of Islamic rural banks as the best model of community banking.

\section{Hypothesis Development}

The social performance of microfinance institutions (MFIs) is reflected in the extent to which microfinance institutions impacts economic development, or how far MFIs have achieved their goals in providing social benefits to the poor. Theoretically, social performance of MFIs indicates how far the financial institutions have served low-income communities or segments that are excluded by conventional financial institutions. ${ }^{18}$ This social performance is also defined as the effective realization of an MFI's social mission into practice which includes increasing outreach, improving the socio-economic condition of clients, and enhancing the social responsibility of MFIs to clients, employees, and the community at large. ${ }^{19}$ Thus social performance is the final assessment of the ability of microfinance institutions to run their social mission, which is to overcome poverty. In principle, the concept of social performance of microfinance institutions (MFIs) is analogous to the concept of social performance in Islamic

Development and Technology, 9.500 (2010), 519; Esubalew Assefa, Niels Hermes, and Aljar Meesters, 'Competition and the Performance of Microfinance Institutions', Applied Financial Economics, 23.9 (2013), 767-82 <https://doi.org/https://doi.org/10.1080/09603107.20 $12.754541>$.

17 Zerai and Rani; Gashayie; Adams and Tewarib; Axmann; Robert Cull, World Bank, and and Asli Demirgüç-kunt World Bank, 'Financial Performance and Outreach: A Global Analysis of Leading Microbanks', MicroBanking Bulletin Project.
${ }^{18}$ Mersland and Strøm; Manfred Zeller, Cécile Lapenu, and Martin Greeley, 'Measuring Social Performance of Microfinance Institutions: Final Report of Social Performance Indicators Initiative ( SPI )', Consultative Group to Assist the Poorest (CGAP), October (2003).

${ }^{19}$ Bert D’Espallier, Marek Hudon, and Ariane Szafarz, 'Aid Volatility and Social Performance in Microfinance', Nonprofit and Voluntary Sector Quarterly, 46.1 (2017), 116-40; S Hashemi and M Anand, 'Toward a Social Performance Bottom Line in Microfinance', Washington DC, CGAP, 2007. 
rural banks because this institution is classified as a microfinance institution.

As in other microfinance institutions, the achievement of social performance in Islamic rural banks can be measured by the outreach or by the impact assessment of a program with respect to the target community. Although these two indicators can be used as a measurement tool, outreach is more popularly used to show how far MFIs have reached their goals in providing social benefits for the lowincome community. ${ }^{20}$ This indicator can function as the best proxy about how far an MFI has achieved its goal of providing social benefits. In other words, the social performance of Islamic rural banks is reflected by the number of clients served by the institution.

Social performance is not similar to social impact such as the change in welfare among clients. If social impact only measures the direct social impact of a disbursed financing, social performance has a broader and more sustainable. Social performance is defined as the effective transference of an MFI's social mission into practice, such as increasing outreach, improving the socio-economic conditions of clients, and enhancing the social responsibility of MFI to the community. This is in line with the main goal of the microfinance institution, to overcome poverty through lending or other financial services which

${ }^{20}$ Mark Schreiner, 'Aspects of Outreach: A Framework for Discussion of the Social Benefits of Microfinance', Journal of International Development, 14.5 (2002), 591-603 < https://doi.org/10.1002/jid.908>; Gary Woller, 'Evaluating MFIs' Social Performance: A Measurement Tool', in Micro Report 35, 2006; Junyon Im and Sunny Li Sun, 'Profits and Outreach to the Poor: The Institutional Logics of Microfinance Institutions', Asia Pacific Journal of Management, 32.1 (2015), 95-117.

21 Niels Hermes and Robert Lensink, 'Microfinance: Its Impact, Outreach, and Sustainability', World Development, 2011, 875-81 <https://doi.org/10.1016/j.worlddev.2009.10.021>; Schreiner.

22 Anne-lucie Lafourcade and others, 'Overview of the Outreach and Financial Performance of Microfinance Institutions in Africa', Microfinance Information EXchange; Washington; DC. Http://Www. ensures that the community and micro-to-small sector are mutually sustainable.

Although outreach is a multidimensional concept, in general this concept refers to the number of clients served. Outreach is defined as the effort to expand microfinance services for people who are not served by financial institutions, or the level to which MFIs have succeeded in attaining clients for financial service. ${ }^{21}$ Outreach has been classified as the effort to extend microfinance services to the people who are underserved by conventional financial institutions. It can be measured in terms of breadth, by using the number of clients served, or by the depth, by using the socioeconomic level of clients that the MFIs can reach. ${ }^{22}$ Indeed, according to Rhyne ${ }^{23}$, two popular aspects of outreach were the depth of outreach and the breadth of outreach. Both point to the poverty level of the client served and the number of people served by the MFIs. This concept is widely used in the literature as a measurement of the social performance of a microfinance institution. Furthermore, other studies recommend the breadth of outreach as a more appropriate measure for measuring social performance for financial institutions with institutionalist approaches such as rural banks ${ }^{24}$.

The concept of social performance is in line with the values of Islamic banks. Islamic Banks are responsible for financial accessibility

Mixmarket. Org/Medialibrary/Mixmar, 2005; K. Rama Mohana Rao and Tamrat Ludego Fitamo, 'Concepts And Measures of Outreach and Sustainability in Microfinance Institutions: A Comprehensive Literature Review', Research Journal of Finance and Accounting, 5.21 (2014), 4149

${ }^{23}$ Elisabeth Rhyne, 'The Yin and Yang of Microfinance: Reaching the Poor and Sustainability', Microbanking Bulletin. Issue, 2.1 (1998), 6-8.

${ }^{24}$ Hesi Eka Puteri, 'The Outreach of Microfinance Institution in West Sumatera Indonesia' (Universitas Andalas Indonesia, 2017); Hidayatul Arief, Iiz Izmuddin, and Hesi Eka Puteri, 'Pengaruh Financial Sustainability Terhadap Jangkauan BPR Syariah Di Propinsi Sumatera Barat', Ekonomika Syariab: Journal of Economic Studies, 3.2 (2019), 32-46. 
among poor Muslim communities and are required to have a bigger involvement in social welfare. The concept of social performance in Islamic banks is part of the Islamic bank's commitment, achieving the economic goals of Islamic teachings, that is maqaasid al-shari'ah, which includes social justice, equitable distribution of income and wealth, and also a sustainable economic development. Although the concept of the common good (mashlaha) in Islam has become the foundation of the existence of Islamic banks, they are subject to much criticism, because they tend to behave as profit-oriented entities rather than social-based entities. Thus, Islamic banks' objectives should be in line with the objectives of Islamic economics itself, which implements maqasid alshari'ab in a holistic way. ${ }^{25}$

The topic of commercialization in microfinance was studied for the first time by Christen, who argues that the commercial approach was made up of three main principles, namely, profitability, competition, and regulation. ${ }^{26}$ This issue has become even more interesting because commercialization causes distraction from the social mission, where microfinance institutions more prefer to target the richer groups of society rather than the lowincome class. The relevant issues of profitability, competition, and regulation must be tested and discussed.

First, profitability. Theoretically profitability is the capability of a company to make a profit by utilizing the total assets owned by the company after adjusting for all costs. Return on Assets (ROA) is one measurement that represents aspects of commercialization in
Islamic rural banks. The bigger ROA, the more profit a bank can make. This number also indicates the operational efficiency of Islamic rural banks. Previous studies have used ROA as a proxy for MFI's profitability ${ }^{27}$ and concluded that profitability negatively affected outreach to the poor, indicating thereby the presence of a trade-off. $^{28}$ There is a relation between profitability and outreach because the decision of a bank to enter a certain market segment is driven by the expected profitability of that market segment. ${ }^{29}$ If a financial institution predicts profit from the market, then it will consider entering the intended market share and expand its outreach. ${ }^{30}$ Based on the related theories and previous studies, the first hypothesis for this study is H1: Profitability is positively associated with the social performance of Islamic rural banks.

Second, regulation. The concept of regulation on rural banks points to the ability of rural banks to execute the intermediary function, namely the function of banks to accumulate third-party funds and channeling them to clients. The ratio used for the proxy is the Capital Adequacy Ratio (CAR) because it has a major influence on lending and ensuring the sustainability of financial institutions. Capital is a major factor for a bank to be able to develop its business growth. CAR played an important role in expanding the MFIs network and ensuring its sustainability. Furthermore, capital adequacy is an important factor in the sustainability of any kind of business organization that uses public money such as banking. A number of studies have linked capital structure to financial performance but
${ }^{25}$ Mustafa Omar Mohammad and Syahidawati Shahwan, 'The Objective of Islamic Economic and Islamic Banking in Light of Maqasid Al-Shariah: A Critical Review', Middle-East Journal of Scientific Research, 13.13 (2013), 75-84.

${ }^{26}$ Robert Peck Christen, 'Commercialization and Mission Drift: The Transformation of Microfinance in Latin America' (Washington, DC: World Bank Group., 2001); Robert Peck Christen, Deborah Drake, and Elisabeth Rhyne, The Commercialization of Microfinance:
Balancing Business and Development, Bloomfield: Kumarian Press., 2002.

${ }^{27}$ Kipesha and Zhang; Piot-lepetit and Nzongang.

${ }^{28}$ Kipesha and Zhang; Hermes and Lensink.

${ }^{29}$ Bresnahan and Reiss.

${ }^{30}$ Hesi Eka Puteri, 'Kontribusi BPRS dalam Merealisasi Financial Inclusion di Pedesaan: Evaluasi Empiris dan Penguatan Strategi', Islam Realitas: Journal of Islamic \& Social Studies, 1.1 (2015), 19-34. 
did not elaborate on its effects on social performance. ${ }^{31}$ The main function of capital is to serve, as loan support if the possible losses arises. Capital is useful as an "engine and better the capital, the more the financial institution will be able to face losses and avoid bankruptcy ${ }^{32}$. Changing the business model due to regulations leads to higher costs per dollar lent and cutting the outreach to the lending sector. ${ }^{33}$ The second hypothesis that needs to be verified is H2: Regulation is positively associated with the social performance of Islamic rural banks.

Third, competition. The concept of competition in Islamic Rural Banks indicates the ability of banks to compete and survive in providing microfinance services, by encouraging the creation of product differentiation with interest rates as an instrument. ${ }^{34}$ Excellence in offering competitive interest rates or financing margins can expand the outreach of microfinance institutions. ${ }^{35}$ There was a significant negative effect between competition and outreach ${ }^{36}$, where the increase in competition can reduce the number of clients and cause inefficiency in MFIs. However, other studies have shown that although the effect of competition was negative on financial selfsufficiency, it did not limit the extent of outreach. The third hypothesis in this study is H3: Competition is negatively associated with the social performance of Islamic rural banks. bumper" for MFIs in the event of a shock. The

\section{Measuring the Impact of Commercialization Factors on the Social Mission}

This research is a field survey with a quantitative approach, which was conducted at six units of Islamic Rural Banks in the West Sumatra province from 2012 to 2018. Panel regression analysis is used to estimate the impact of commercialization factors which consist of profitability, competition, and regulation on the social performance of Islamic rural bank.

The population of this study are seven units of Islamic rural banks in the West Sumatra Province of Indonesia. Research was carried out from 2012 to 2018. These seven units of Islamic rural banks were geographically dispersed in several districts and cities, consisting of Agam District, Lima Puluh Kota District, Tanah Datar District, Pasaman Barat District, Sawahlunto City, and Solok City. This sample was chosen with the consideration that the six rural banks have complete financial reports for the period analyzed. Data about clients and financing margins were obtained from the financial report at the Islamic rural banks itself, while other data were obtained from the audited financial report published by the Financial Services Authority.

To predict the model, the dependent variable in this research is Social Performance, which is proxied by the number of clients (NOC). The number of clients refers to the number of active financing customers in rural banks in the year observed. NOC was selected as a proxy with the consideration that the instrument was the best proxy for social performance, especially for MFIs, which have

${ }^{31}$ Haruna Sekabira, 'Capital Structure and Its Role on Performance of Microfinance Institutions: The Ugandan Case', Sustainable Agriculture Research, 2.3 (2013), $86<$ https://doi.org/10.5539/sar.v2n3p86>; Vicki L Bogan, 'Capital Structure and Sustainability: An Empirical Study of Microfinance Institutions', Review of Economics and Statistics, 94.4 (2012), 1045-58 <https://doi.org/https://doi.org/10.1162/REST_a_00 223>; Vicki Bogan, Willene Johnson, and Nomathemba Mhlanga, Microfinance Institution Capital Structure and Financial Sustainability (Working Papers, 2007).
Ngambi.

33 Axmann.

${ }^{34}$ Paolo Casini, 'Competition and Altruism in Microcredit Markets', Unpublished, Université Libre de Bruxelles, Brussels, 2008.

35 Adams and Tewarib.

${ }^{36}$ Cloet and Moyaert; Olsen; Assefa, Hermes, and Meesters.
${ }^{32}$ Cull, Demirguc-Kunt, and Morduch; Gwasi and 
an institutionalist approach. ${ }^{37}$ The independent variables in the model are profitability, regulation and competition. Profitability is proxied by Return on Assets (ROA), which refers to the ratio used to measure the net income earned by banks from the use of total assets. ROA is calculated by dividing a bank's net income by total assets. In banking literature, Return on Assets (ROA) is one of the most highlighted profitability ratios, because it can show the success of banks in creating profits. ROA is also able to quantify the bank's ability to generate profits in the past and then projected to the future.

The regulation was proxied by Capital Adequacy Ratio (CAR), which refers to the ability of banks to provide funds used to overcome the possible risk of loss. This ratio is calculated by dividing a bank's capital by its riskweighted assets. This proxy was chosen because CAR is the most appropriate concept in reflecting the implementation of regulations in a bank, specifically the bank's function as an intermediary institution that collects third party funds and then distributes them in financing.

The competition is proxied with the murabaha margin. The murababa margin is the percentage of profit rate negotiated by the bank and the client of murababa financing. This proxy was considered as the most appropriate instrument because the reflection of the competition is the interest rates, ${ }^{38}$ and the exact equivalent for interest rates in Islamic rural banks is the murabaha margin.

\section{Data Analysis Method}

Panel regression analysis was implemented in analyzing the empirical model. The functional equation that will be estimated is as follows:

$N O C_{i t}=\beta_{0}+\beta_{1} R O A_{i t}+\beta_{2} C A R_{i t}+\beta_{3} \operatorname{Margin}_{i t}+\varepsilon_{i t}$

Refer to the above equation, NOC is the number of clients (a proxy for social performance); ROA is Return on Assets (a proxy of profitability); CAR is Capital Adequacy Ratio (a proxy for regulation); and Margin is murabaha margin (a proxy for competition).

To forecast the rate of constant and also the regression coefficient, the panel data regression considered three models, which consist of Pooled Least Squared (PLS), Fixed Effect Models (FEM) and Random Effect Models (REM). Several tests were carried out to select the three alternatives, which included The Chow test, Breusch Pagan Lagrange Multiplier (LM) test and Hausman test.

Chow test is implemented to choose a preferable model between Pooled Least Squared (PLS) and Fixed Effect Models. The Breusch Pagan Lagrange Multiplier (LM) is used to choose which model is more appropriate to use, whether the Pooled Least Squared (PLS) or Random Effect Model (REM). Then, the Hausman test was implemented to choose the best alternative model among the Fixed Effect Model (FEM) or the Random Effect Model (REM). After obtaining the best model, the next step of testing was done by conducting the Ftest, t-test or z-test and R-squared to examine the effect of predictors on the dependent variable.

\section{The Impact of Commercialization Factors on the Social Mission of IMFs}

To answer the hypotheses in this research, the analysis of the causal relationships between profitability, regulation, and competition to the social performance of Islamic rural banks were implemented. The panel data regression was conducted in the three estimation models consisting of the Pooled Least Squared, the Fixed Effect Model, and the Random Effect Model. These results are presented in Table 1 
Table 1. Estimation Results of the Panel Data Regression

\begin{tabular}{|c|c|c|c|}
\hline Model & Var. & $\begin{array}{c}\mathrm{t}- \\
\text { Statistic } \\
\text { or } \mathrm{z}- \\
\text { Statistic }\end{array}$ & Prob. \\
\hline \multirow{4}{*}{$\begin{array}{l}\text { Pooled least squared } \\
(P L S) \\
\text { Prob }>\mathrm{F}=0.000 \\
\text { R-Squared }=0.2798 \\
\mathrm{n}=168\end{array}$} & Cons & 5.88 & 0.000 \\
\hline & $\mathrm{ROA}$ & 3.82 & 0.000 \\
\hline & CAR & -2.24 & 0.027 \\
\hline & Margin & -4.70 & 0.000 \\
\hline \multirow{4}{*}{$\begin{array}{l}\text { Fixed Effect Model } \\
(\text { FEM) } \\
\text { Prob }>\text { F }=0.0293 \\
\text { R-Squared }=0.0568 \\
n=168\end{array}$} & Cons & 0.39 & 0.695 \\
\hline & ROA & 2.62 & 0.010 \\
\hline & CAR & 1.13 & 0.260 \\
\hline & Margin & 0.01 & 0.412 \\
\hline \multirow{4}{*}{$\begin{array}{l}\text { Random Effect Model } \\
(\text { REM) } \\
\text { Prob }>\text { chi } 2=0.0002 \\
\text { R-Squared }=0.2213 \\
\mathrm{n}=168\end{array}$} & Cons & 4.68 & 0.000 \\
\hline & ROA & 2.50 & 0.012 \\
\hline & CAR & -0.45 & 0.650 \\
\hline & Margin & -3.23 & 0.001 \\
\hline
\end{tabular}

After applying the three alternative estimation models consisting of the PLS, Fixed Effect Model and Random Effect Model, the next step is to do some more testing to see which is the most statistically stable among the three models. These tests cover the Chow Test, the LM Test and the Hausman Test. The result is shown in Table 2.

Table 2. Selection of Panel Data Regression Model

\begin{tabular}{lc}
\hline \multicolumn{1}{c}{ Model Estimation } & Probability \\
\hline Chow Test & 0.0000 \\
\hline Breusch Pagan Lagrange & 0.0000 \\
Multiplier (LM) test & \\
\hline Hausman Test & 0.4712
\end{tabular}

Source: secondary data processed, 2020

The results of the Chow Test show the Probability $>F=0.000$, which means that the PLS model was rejected and the Fixed Effect Model was accepted. The Breusch Pagan Lagrange Multiplier (LM) test also resumed that Probability $>F=0.000$, which also means the rejection of the PLS model and decided to use the Random Effect Model. Furthermore, the Hausman test was applied for testing the choice between the Fixed Effect Model and the Random Effect Model, which then appeared with Probability $>F=0.4712$. Thus, the model used was the Random Effect Model, as shown in Table 3 below:

Table 3. Result of Panel Regression with Random Effect Model

\begin{tabular}{lccc}
\hline \multicolumn{1}{c}{ Variable } & Coefficient & $\begin{array}{c}\text { Standard } \\
\text { Error }\end{array}$ & Prob. \\
\hline $\begin{array}{l}\text { Profitability } \\
\text { (ROA) }\end{array}$ & 18.9473 & 7.57682 & 0.012 \\
\hline $\begin{array}{l}\text { Regulation } \\
\text { (CAR) }\end{array}$ & -2.7530 & 6.07228 & 0.650 \\
\hline $\begin{array}{l}\text { Competition } \\
\text { (Margin) }\end{array}$ & -143.6566 & 44.54071 & 0.001 \\
\hline constant & 3004.3150 & 642.49170 & 0.000 \\
\hline $\begin{array}{l}\text { Prob }>\text { Chi2 }=0.0002, \text { R-Squared }=0.2213 \\
\text { Source: secondary data is processed, } 2020\end{array}$ \\
$\begin{array}{l}\text { The results in Table } 3 \text { show the significant } \\
\text { influence of profitability, regulation, and } \\
\text { competition on the social performance of }\end{array}$
\end{tabular}
Islamic rural banks. On the whole, the results of the Random Effect Model were quite good and could be accepted statistically (Probability $>$ Chi2 $=0.0002$, R-Squared $=0.2213$ ) .

To verify the hypothesis in this study, the results in Table 3 can be further analyzed. The estimation coefficient showed that there was a positive influence between profitability, which was proxied by ROA, on the social performance (coefficient $=18.9473$, $\mathrm{p}$-value $=0.012)$. Thus, H1-Profitability is positively associated with social performance-is acceptable. Increasing ROA causes an increase in the number of clients of Islamic rural banks, which then increases the social performance of banks. Thus, an increase in profitability has an impact on the increase of the social performance of Islamic rural banks. The role of Islamic rural banks in economic development will increase if the profitability of rural banks also increases. An Islamic rural bank will always provide social benefits to the community, especially the poor Muslim community, if the institution is financially profitable.

Next, the results showed that there was no significant effect of regulation, which was proxied by CAR, on the social performance of 
Islamic rural banks (coefficient $=-2.7530, \mathrm{p}$ value $=0.650)$. The findings of this study indicated that regulation did not affect the social performance of Islamic rural banks. The Bank's financial ability to increase the Capital Adequacy Ratio (CAR) as a proxy for regulation did not affect the increase in the number of clients. Thus, H2-Regulation is positively associated with the social performance of Islamic rural banks-is rejected. Increasing CAR had no effect in increasing the number of clients of Islamic rural banks, and thus has no effect in increasing the social performance of the rural banks. It can be concluded that there is no guarantee that the reinforcement of the regulation of Islamic rural banks would have a positive impact on improving their social performance.

Furthermore, the estimated coefficient of 143.6566 ( $\mathrm{p}$-value $=0.001)$ shows that competition which was proxied by the murabaha margin negatively affected the social performance of Islamic rural banks. Thus, H3 - Competition is negatively associated with the social performance of Islamic rural banksis acceptable. The higher the rate of murababa margin causes a decrease in the number of clients, which also means a decrease in the social performance of Islamic rural banks.

The findings of this research have empirically proven that the commercialization factors which include profitability, regulation, and competition are the determinants of social performance in Islamic rural banks. Thus, there are several implications of this finding that can contribute to further studies in the field of social performance in Islamic banking. First, this finding shows that the role of Islamic rural banks in economic development is strongly influenced by commercialization factors such as profitability, regulation, and competition. When

${ }^{39}$ Caserta, Monteleone, and Reito; Gakhar and Meetu; Lebovics, Hermes, and Hudon; Qinlan and Izumida; Zerai and Rani. a number of determinants are organized precisely, Islamic rural banks as MFIs can attain their dual objectives of social performance and financial performance while also carrying out their "ultimate promise" as community banking. This finding reinforces previous studies that show that the two objectives of MFIs could be achieved simultaneously. ${ }^{39}$

This finding provides evidence that Islamic banks are more than banks with the primary function of collecting and distributing public funds, but are also committed to carrying out social functions that advances economic empowerment. The purpose of Islamic banks is not just profit. They are also oriented to the public good. Thus, Islamic banks should promote the objectives of Islamic economics by inculcating the maqasid al-shari'ah in a holistic way. ${ }^{40}$

Second, Islamic rural banks will only improve their social performance significantly if only their financial performance is also strong, especially profitability. Like other microfinance institutions, Islamic rural banks are not designed only for poor people and are not subsidized by the government. These financial institutions will be able to enact their social functions if they are not financially sustainable. As an indicator of self-sufficiency in finance, profitability has been considered as a strong predictor of the social performance of Islamic rural banks. The higher the profitability, the higher the ability of banks to carry out their social functions by channeling loans at small ceilings to poor people. Theoretically, smallceiling loans are assumed to increase operating costs, and this can only be done by rural banks with high profitability. Thus, the higher the profitability, the easier it will be for banks to carry out their social functions. This finding contradicted previous studies that concluded that there is a negative connection between

${ }^{40} \mathrm{Habib}$ Ahmed, 'Maqasid Al-Shari'ah and Islamic Financial Products: A Framework for Assessment.', ISRA International Journal of Islamic Finance, 3.1 (2011), 149-60; Mohammad and Shahwan. 
Return on Assets (ROA) and outreach ${ }^{41}$ as one indicator of the social function. Thus, this research concludes that the two aims of MFIs could be achieved at the same time, and there is no trade-off between profitability and the achievement of social function for rural banks.

Third, regulation does not affect the improvement of social performance. Even though the regulations have been devised by the government, such as the requirements to maintain the capital adequacy ratio which the attendants prepare for the risk of losses, this does not guarantee that Islamic rural banks will improve their social performance. Requirements to maintain the bank's adequacy ratio play a role in maintaining the capital structure, but they do not increase the loan extended by banks. The different proxies used lead to different findings that prove the absence of any relationship between regulation and social performance. Previous arguments stating that "the greater the capital, the better the social performance" have not been proven in this case. The capital structure might regenerate the efficiency of MFIs and also financial sustainability ${ }^{42}$, but it does not guarantee improvement in social function.

Fourth, financing margins can improve the social performance of Islamic rural banks through increasing outreach to Muslim communities. Relevant findings were also found in previous studies which concluded that there was an influence of competition on social performance. Thus, our findings are in line with previous findings. ${ }^{43}$ In general, our findings confirm that competitive interest rates are still a consideration for banks or other financial institutions to increase the number of clients and accelerate the increase of social performance.

Based on these findings, it is clear that in the absence of any regulation that support the existence of the Islamic rural bank, competition can degenerate the sustainability of this microfinance institution. This problem occurs because the same segment is also targeted by other financial institutions which are sometimes stronger in its capital structure. The social performance of Islamic rural banks will decrease if the competition of financial institutions in the same market segment becomes more imbalanced. Although the result of this present study is relevant to several previous studies that also found a significant relationship between competition and outreach $^{44}$, these findings will remain interesting to be discussed in future studies. Issues regarding the relationship between competition and social performance have always been an interesting discussion because these two things are contradictory. Competition is needed to increase competitiveness, but on the other hand it also causes reduced outreach

Islamic rural banks, which are nonsubsidized microfinance institutions, are greatly affected by the prime lending rate or financing margin. Higher prime lending rates or financing margins will result in fewer clients, which means that rural banks are unable to fulfill their social functions. The level of financing margin in Islamic rural banks is sometimes like a "doubleedged sword". Islamic rural banks which are non-subsidized microfinance institutions are greatly affected by the financing margin. Higher the financing margin will result in fewer clients, which means that rural banks would face more difficulty in fulfilling their social functions. High financing margins can bring profits to banks and generate positive spreads, but on the other hand, they can result in rural banks being abandoned by clients. This highlights the importance of economic efficiency in Islamic rural banks. It would be difficult to declare that Islamic rural banks are community banking and others.

${ }^{41}$ Kipesha and Zhang; Abdulai and Tewari; Huq

${ }^{42}$ Bogan.

\footnotetext{
${ }^{43}$ Adams and Tewarib.

${ }^{44}$ Cloet and Moyaert; Olsen.
} 
institutions that support development in the rural areas if the financing margins are unafforfdable.

This research contributes to the scholarship surrounding the question of how Islamic banks can participate in efforts to develop the economy without ignoring the concept of commercialization. In other words, this study can show the relationship between financial sustainability and the social goals of a financial institution. In principle this problem is analogous to the behavior of individuals in issuing infaq or sadaqa (charity), which only they pay out when they have excess assets. Islamic financial institutions are not social institutions that will serve poor people by ignoring their financial goals. The social function will only be carried out if Islamic rural banks are profitable and other factors such as regulation and competition are also supportive.

Finally, this paper concludes that to achieve the dual goals of Islamic microfinance, namely good financial performance and social performance, Islamic rural banks must be able to practice microfinance while maintaining institutional viability, competitiveness and sustainability. There is a fundamental difference between Islamic banking and conventional banking, not only in the way they organize their business but above all the values which guide Islamic banking itself. ${ }^{45}$ The prevailing values in the shariah are expressed not only in the transactions and the system but in the breadth of its role in the Muslim community's effort in sustaining economic development.

\section{Conclusion}

Based on the results above, this study shows that there are significant impacts of profitability and competition on the social performance of Islamic rural banks. It also shows that regulation does not affect the improvement of social performance, although this factor was predicted to have an impact on social performance. Capital structure might improve financial sustainability, but does not guarantee an improvement in social performance.

Thus, this finding shows that the policy to expand Islamic rural banks' outreach to the Muslim community in order to improve their social performance can be achieved by strengthening the commercialization factors such as profitability and competition. Efforts to increase profitability can increase social performance, as well as reduce financing margins. Both these policies are the best solutions to improve the social performance of Islamic rural banks, and to allow them to become more than just a profit-oriented institution, but instead to become a community banking institution for the Muslim poor in rural areas.

Despite these findings that empirically explain the impact of commercialization factors, further studies are needed that would include more study cases and introduce more control variables in the model. The limitation of this study is in the limited selection of the unit of analysis, as there are only six units of Islamic rural banks in the West Sumatra Province that were analyzed from 2012 to 2018. As mentioned above, this limited selection was due to the limited availability of financial data. Furthermore, although the concept of social performance is multidimensional, this study limits the analysis of social performance to the concept of outreach as measured by the number of clients. Although the concept of this measurement is quite representative of the achievements of the social performance of an Islamic rural bank, of course this measurement

Banking and Finance, 37.2 (2013), 433-47 <https://doi.org/10.1016/j.jbankfin.2012.09.016>; Muhammad Hanif, 'Differences and Similarities in Islamic and Conventional Banking', International Journal of Business and Social Sciences, 2.2 (2014). 
has not fully characterized the distinctions of an Islamic financial institution

Apart from the above limitations, we believe that this investigation has produced an accurate and well-substantiated picture of social performance of a microfinance institution with an institutionalist approach, namely Islamic rural banks.

\section{References}

Books

Arsyad, Lincolin, Microfinance Institutions, Institutional Performance and Sustainability (Yogyakarta: Andi Offset, 2008)

Bateman, Milford, The Rise and Fall of Muhammad Yunus and the Microcredit Model, Management: Leading \& Collaborating in Competitive World, 11Th Edition (UK: McGraw-Hill Education, 2014)

Christen, Robert Peck, Commercialization and Mission Drift: The Transformation of Microfinance in Latin America'(Washington DC: World Bank Group, 2001) , Deborah Drake, and Elisabeth Rhyne, The Commercialization of Microfinance: Balancing Business and Development (Bloomfield: Kumarian Press, 2002)

Cull, Robert, Asli Demirguc-Kunt, and Jonathan Morduch, Microfinance Tradeoffs: Regulation, Competition, and Financing In The Handbook of Microfinance (UK: The Handbook Of Microfinance, 2011)

Hashemi, S, and M Anand, Toward a Social Performance Bottom Line in Microfinance, (Washington DC: CGAP, 2007)

Mersland, Roy, and R Øystein Strøm, 'Microfinance Financial and Social Performance: An Introduction in Microfinance Institutions', in Microfinance Institutions (London: Palgrave Macmillan \& Springer, 2014)

Puteri, Hesi Eka, The Outreach of Microfinance Institution in West Sumatera Indonesia (Padang: Universitas Andalas Indonesia, 2017)

Yunus, Muhammad, Creating a World Without Poverty: Social Business and the Future of
Capitalism (New York: Public Affairs, 2009)

\section{Journals}

Abdulai, Adams, and Devi Datt Tewari, 'Tradeoff Between Outreach and Sustainability of Microfinance Institutions: Evidence From Sub-Saharan Africa', Enterprise Development and Microfinance, 28.3 (2017), 162-81 <https://https://doi.org/17551986.16-00014>

Adams, Abdulai, and Devi D. Tewarib, 'Determinants Of Microfinance Outreach In Sub-Saharan Africa: A Panel Approach', Acta Commercii, 17.1 (2017), 110

<https://doi.org/10.4102/ac.v17i1.414>

Ahmed, Habib, 'Maqasid Al-Shari'ah and Islamic Financial Products: A Framework for Assessment.', ISR A International Journal of Islamic Finance, 3.1 (2011), 149-60

Amelec, Viloria, and Vasquez Carmen, 'Relationship Between Variables of Performance Social and Financial of Microfinance Institutions', Advanced Science Letters, $21.6 \quad$ (2015), 1931-34 <https://doi.org/https://doi.org/10.116 6/asl.2015.6163>

Arief, Hidayatul, Iiz Izmuddin, and Hesi Eka Puteri, 'Pengaruh Financial Sustainability Terhadap Jangkauan BPR Syariah di Propinsi Sumatera Barat', Ekonomika Syariah: Journal of Economic Studies, 3.2 (2019), 32-46

Arsyad, Lincolin, 'Microfinance Institutions, Institutional Performance and Sustainability', Andi Offset. Yogyakarta, 2008

Assefa, Esubalew, Niels Hermes, and Aljar Meesters, 'Competition and the Performance of Microfinance Institutions', Applied Financial Economics, 23.9 (2013), 767-82 <https://doi.org/https://doi.org/10.108 0/09603107.2012.754541>

Axmann, Nikolaus, What Is the Effect of Regulatory Supervision on the Profitability and Outreach of Microfinance Institutions?', Southeast Asian Journal of Economics, 3.1 (2015), 1-25 
Basah, Mohamad Yazis Ali, and Mazlynda Md Yusuf, 'Islamic Bank and Corporate Social Responsibility (CSR)', European Journal of Business and Management, 5.11 (2013), 194209

Bassem, B E N Soltane, 'Social and Financial Performance of Microfinance Institutions: Is There a Trade-Off?', Journal of Economics and International Finance, 4.4 (2012), 92-100

Bateman, Milford, The Rise and Fall of Muhammad Yunus and the Microcredit Model, Management: Leading \& Collaborating in Competitive World, 11Th (Edition. McGraw-Hill Education, 2014)

Beck, Thorsten, Asli Demirgüç-Kunt, and Ouarda Merrouche, 'Islamic vs. Conventional Banking: Business Model, Efficiency and Stability', Journal of Banking and Finance, 37.2 (2013), 433-47 <https://doi.org/10.1016/j.jbankfin.201 2.09.016>

Bogan, Vicki, Willene Johnson, and Nomathemba Mhlanga, Microfinance Institution Capital Structure and Financial Sustainability (Working Papers, 2007)

Bogan, Vicki L, 'Capital Structure and Sustainability: An Empirical Study of Microfinance Institutions', Review of Economics and Statistics, 94.4 (2012), 104558

$<$ https://doi.org/https://doi.org/10.116

2/REST_a_00223>

Bresnahan, Timothy F, and Peter C Reiss, 'Entry And Competition In Concentrated Markets', Journal of Political Economy, 99.5 (1991), 977-1009

Caserta, Maurizio, Simona Monteleone, and Francesco Reito, 'The Trade-off Between Profitability and Outreach in Microfinance', Economic Modelling, 72 (2018), 31-41 <https://doi.org/https://doi.org/10.101 6/j.econmod.2018.01.003>

Casini, Paolo, 'Competition and Altruism in Microcredit Markets', Unpublished, Université Libre de Bruxelles, Brussels, 2008

Christen, Robert Peck, 'Commercialization and
Mission Drift: The Transformation of Microfinance in Latin America' (Washington, DC: World Bank Group., 2001)

Christen, Robert Peck, Deborah Drake, and Elisabeth Rhyne, The Commercialization of Microfinance: Balancing Business and Development, Bloomfield: Kumarian Press., 2002

Cloet, Arne De, and Hartwig Moyaert, Microfinance: Influence of Competition on Outreach, Published Thesis of Ghent University, 2014

Cull, Robert, World Bank, and and Asli Demirgüç-kunt World Bank, 'Financial Performance and Outreach: A Global Analysis of Leading Microbanks', MicroBanking Bulletin Project

Cull, Robert, Asli Demirguc-Kunt, and Jonathan Morduch, Microfinance Tradeoffs: Regulation, Competition, and Financing In The Handbook of Microfinance (The Handbook Of Microfinance, 2011)

Cull, Robert, Asli Demirgüç-Kunt, and Jonathan Morduch, 'Does Regulatory Supervision Curtail Microfinance Profitability and Outreach?', World Development, $39.6 \quad$ (2011), 949-65 <https://doi.org/10.1016/j.worlddev.20 09.10.016>

D'Espallier, Bert, Marek Hudon, and Ariane Szafarz, 'Aid Volatility and Social Performance in Microfinance', Nonprofit and Voluntary Sector Quarterly, 46.1 (2017), 116-40

Gakhar, Kamlesh, and Meetu, 'Financial Performance and Outreach of Microfinance Institutions: Is There a Trade-Off? - An Empirical Study of Indian', Sona Global Management Review, 7.4 (2013), 1-10

Gashayie, Aderaw, 'Factors That Affect Financial Sustainability of Microfinance Institution: Literature Review', European Journal of Business and Management, 7.7 (2015), 223-29

Grassa, Rihab, and Hamadi Matoussi, 'Corporate Governance of Islamic Banks: 
A Comparative Study between GCC and Southeast Asia Countries', International Journal of Islamic and Middle Eastern Finance and Management, 7.3 (2014), 346-62

Gwasi, Ndi, and Marcel T. Ngambi, 'Competition and Performance of Microfinance Institutions in Cameroon', International Journal of Research In Social Sciences, $\quad 3.8 \quad$ (2014), 1-36 $<$ https://doi.org/10.2139/ssrn.2029568 $>$

Hanif, Muhammad, 'Differences and Similarities in Islamic and Conventional Banking', International Journal of Business and Social Sciences, 2.2 (2014)

Hashemi, S, and M Anand, 'Toward a Social Performance Bottom Line in Microfinance', Washington DC, CGAP, 2007

Hermes, Niels, and Robert Lensink, 'Microfinance: Its Impact, Outreach, and Sustainability', World Development, 2011, 875-81

<https://doi.org/10.1016/j.worlddev.20 09.10.021>

Huq, Begum Ismat Ara, Md. Abul Kalam Azad, Abdul Kadar Muhammad Masum, Peter Wanke, and Md. Azizur Rahman, 'Examining the Trade-off Between Social Outreach and Financial Efficiency: Evidence from Microfinance Institutions in South Asia', Global Business Review, 18.1 (2017), 617-828 <https://doi.org/10.1177/097215091769 2169>

Im, Junyon, and Sunny Li Sun, 'Profits and Outreach to the Poor: The Institutional Logics of Microfinance Institutions', Asia Pacific Journal of Management, 32.1 (2015), 95-117

Kaur, Prabhjot, 'Outreach and Sustainability of Microfinance Institutions in India in Pre and Post Andhra Pradesh Microfinance Crisis in Context of South Asia', Global Journal of Finance and Management, 6.6 (2014), 569-74

Khan, Feisal, 'How 'Islamic' Is Islamic Banking?', Journal of Economic Behavior \& Organization, 76.3 (2010), 805-20
Kipesha, Erasmus Fabian, and Xianzhi Zhang, 'Sustainability, Profitability, and Outreach Tradeoffs: Evidence from Microfinance Institutions in East Africa', European Journal of Business and Management, 5.8 (2013), 136-49

Lafourcade, Anne-lucie, Jennifer Isern, Patricia Mwangi, and Matthew Brown, 'Overview of the Outreach and Financial Performance of Microfinance Institutions in Africa', Microfinance Information EXchange; Washington; DC. Http://Www. Mixmarket. Org/Medialibrary/Mixmar, 2005

Lebovics, Maxime, Niels Hermes, and Marek Hudon, 'Are Financial and Social Efficiency Mutually Exclusive? A Case Study of Vietnamese Microfinance Institutions', Annals of Public and Cooperative Economics, 87.1 (2016), 55-77

Mersland, Roy, and R Øystein Strøm, 'Microfinance Financial and Social Performance: An Introduction in Microfinance Institutions', in Microfinance Institutions (Palgrave Macmillan, London: Springer, 2014), pp. 1-11

Mohammad, Mustafa Omar, and Syahidawati Shahwan, "The Objective of Islamic Economic and Islamic Banking in Light of Maqasid Al-Shariah: A Critical Review', Middle-East Journal of Scientific Research, 13.13 (2013), 75-84

Nathan, Samy, and Vincent Ribière, 'From Knowledge to Wisdom: The Case of Corporate Governance in Islamic Banking', VINE: The Journal of Information and Knowledge Management Systems, 37.4 (2007), 471-83 $<$ https://doi.org/10.1108/030557207108 38533>

Olsen, T D, New Actors in Microfinance Lending: The Role of Regulation and Competition in Latin America', Perspectives on Global Development and Technology, 9.500 (2010), 519

Piot-lepetit, Isabelle, and Joseph Nzongang, 'Financial Sustainability and Poverty Outreach Within a Network of Village Banks in Cameroon: A Multi-DEA Approach', European Journal of Operational 
Research, $234.1 \quad$ (2014), 319-30 $<$ https://doi.org/10.1016/j.ejor.2013.10. 004>

Puteri, Hesi Eka, 'Kontribusi BPRS dalam Merealisasi Financial Inclusion di Pedesaan: Evaluasi Empiris dan Penguatan Strategi', Islam Realitas: Journal of Islamic \& Social Studies, 1.1 (2015), 19-34

- 'The Outreach of Microfinance Institution in West Sumatera Indonesia' (Universitas Andalas Indonesia, 2017)

Qinlan, Zhang, and Yoichi Izumida, 'Determinants of Repayment Performance of Group Lending in China', China Agricultural Economic Review, 5.3 (2013), 328-41

$<$ https://doi.org/10.1108/CAER-082012-0083>

Rao, K. Rama Mohana, and Tamrat Ludego Fitamo, 'Concepts And Measures of Outreach and Sustainability in Microfinance Institutions : A Comprehensive Literature Review', Research Journal of Finance and Accounting, 5.21 (2014), 41-49

Rhyne, Elisabeth, 'The Yin and Yang of Microfinance: Reaching the Poor and Sustainability', Microbanking Bulletin. Issue, 2.1 (1998), 6-8

Schreiner, Mark, 'Aspects of Outreach: A Framework for Discussion of the Social Benefits of Microfinance', Journal of International Development, 14.5 (2002), 591603 <https://doi.org/10.1002/jid.908>

Sekabira, Haruna, 'Capital Structure and Its Role on Performance of Microfinance Institutions: The Ugandan Case',
Sustainable Agriculture Research, 2.3 (2013), 86

$<$ https://doi.org/10.5539/sar.v2n3p86>

Woller, Gary, 'Evaluating MFIs' Social Performance: A Measurement Tool', in Micro Report 35, 2006

Yunus, Muhammad, Creating a World Without Poverty: Social Business and the Future of Capitalism (New York: Public Affairs, 2009)

Zeller, Manfred, Cécile Lapenu, and Martin Greeley, 'Measuring Social Performance of Microfinance Institutions: Final Report of Social Performance Indicators Initiative (SPI)', Consultative Group to Assist the Poorest (CGAP), October (2003)

Zerai, Bereket, and Lalitha Rani, 'Is There a Trade-off Between Outreach and Sustainability of Microfinance Institutions? Evidence from Indian Microfinance Institutions (MFIs)', European Journal of Business and Management, 4.2 (2012), 90-99

Lafourcade, Anne-lucie, Jennifer Isern, Patricia Mwangi, and Matthew Brown, 'Overview of the Outreach and Financial Performance of Microfinance Institutions in Africa', Microfinance Information EXchange; Washington; DC. <http:/www. Mixmarket. Org/Medialibrary/Mixmar, 2005>

Woller, Gary, 'Evaluating MFIs' Social Performance: A Measurement Tool', in Micro Report 35, 2006

Zeller, Manfred, Cécile Lapenu, and Martin Greeley, 'Measuring Social Performance of Microfinance Institutions: Final Report of Social Performance Indicators Initiative (SPI)', Consultative Group to Assist the Poorest (CGAP), October. 2003 